\title{
Linguistic labour: International hospitality employees' use of non-English native language in service encounters
}

\section{David Williamson and Tingting Chen}

Dr David Williamson is a senior lecturer in the School of Hospitality and Tourism, Auckland University of Technology. He spent 18 years working in the hospitality industry as a hotel manager and restaurateur. His research includes work, employment and labour market issues in hospitality and tourism. David completed his PhD in 2017 - a history of employment relations in the New Zealand hotel sector, 1955-2000.

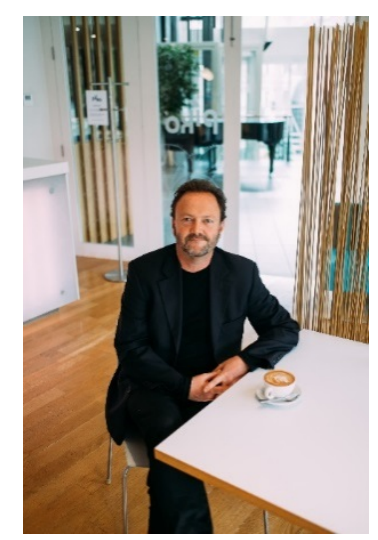

Tingting Chen graduated in 2017 with a Master of International Hospitality Management from the AUT School of Hospitality and Tourism. Her dissertation was titled, 'An examination of international employees' use of native languages in service encounters in the hospitality industry'. She
The enduring growth in the international hospitality and tourism sector, in conjunction with an increasingly globalised labour market, has increased the chances of tourists being served by staff using their shared non-English native language. Numerous studies have explored the use of native language in service encounters, with customer perceptions widely investigated [1,2]. However employees' perspectives of non-English native language use in the servicescape are under-researched. This study is a part of an AUT Master of International Hospitality Management dissertation. The study applied a qualitative methodology, interviewing eight international employees in New Zealand hotels with long-term experience of speaking their non-English native language in service encounters.

Results of the study indicated that employees are well aware of the demands for employers to provide customer-oriented service by speaking their non-English native language; however, in any service encounters with customers speaking the same native language, staff have a strong preference for initiating service communication in English. The interviews showed that this preference was a result of workers experiencing considerable concerns, stress and anxiety around the use of their non-English native language. Specifically, a complex series of considerations and decisions occur when staff are faced with customers who might want to use shared non-English native language, suggesting employees experience 'linguistic labour', similar to the constructs of emotional $[3,4]$ and aesthetic labour [5].

Participants indicated that the choice of using non-English native language may be passive (i.e. following the lead of a guest who recognises the staff member as a fellow speaker), or proactive when workers recognise a customers' poor English and use their native language to minimise guest embarrassment. Given the complexity and distinctiveness of each service context, participants suggested they had principles that underpinned their choice of language in the service space. Firstly, that English is the default service language and should be used as such; secondly, that participants did not want to assume guests' ethnic/language identity and so avoided using their non-English native language; thirdly, participants avoided using non-English native language so as to not be identified as a particular ethnicity. Crucially, participants sought to avoid being ethnically/linguistically pigeonholed, because engaging in shared native language in the servicescape was perceived to lead to significantly increased customer service demands and thus increased workload. In essence, participants 
now works and resides in China.

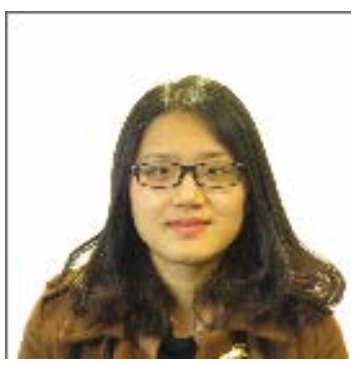

stated that using shared language in the service space immediately engaged cultural norms from their home countries that they would rather avoid; notably increased workloads, guest expectations of subservience and a perceived loss of status and respect for the participants.

The study makes an original contribution to management studies, showing that managers and owners should consider the impacts of linguistic labour on employees in the servicescape. What can appear as a simple request to speak a certain language can engage employees in a complex process of choices and considerations as they try to avoid the perceived work intensification that comes with speaking their non-English native language.

The full dissertation can be accessed here:

https://aut.researchgateway.ac.nz/bitstream/handle/10292/10877/ChenT.pdf?seq uence $=4 \&$ is Allowed $=y$

\section{Corresponding author}

David Williamson can be contacted at: $\underline{\text { david.williamson@aut.ac.nz }}$

\section{References}

((1) Holmqvist, J.; Van Vaerenbergh, Y.; Grönroos, C. Consumer Willingness to Communicate in a Second Language: Communication in Service Settings. Management Decision 2014, 52(5), 950-966. http://hdl.handle.net/1854/LU-3214078

(2) Kang, S.-J. Dynamic Emergence of Situational Willingness to Communicate in a Second Language. System 2005, 33(2), 277-

292. https://doi.org/10.1016/j.system.2004.10.004

(3) Hochschild, A.R. Emotion Work, Feeling Rules, and Social Structure. American Journal of Sociology 1979, 85(3), 551-575. https://doi.org/10.1086/227049

(4) Hochschild, A.R. The Managed Heart: Commercialization of Human Feeling; University of California Press: Berkeley, CA, 1983.

(5) Warhurst, C.; Nickson, D. Employee Experience of Aesthetic Labour in Retail and Hospitality. Work Employment \& Society 2007, 21, 103-

120. https://doi.org/10.1177/0950017007073622 